\title{
Photosynthetic Responses to Lightflecks of Fagus crenata Seedlings Grown in a Gap and Understory of a Deciduous Forest
}

\author{
Masaaki Naramoto, Qingmin Han, ${ }^{1}$ and Yoshitaka Kakubari ${ }^{2}$ \\ Department of Forest Resources, Faculty of Agriculture, University of Shizuoka, Shizuoka 422-8529, Japan.
}

\begin{abstract}
Photosynthetic responses to a series of 1-min lightflecks $\left(1,000 \mu \mathrm{mol} \mathrm{m}^{-2} \mathrm{~s}^{-1}\right)$ superimposed on a background with different duration $(1,5$, and $10 \mathrm{~min})$ and intensity $\left(25\right.$ and $\left.50 \mu \mathrm{mol} \mathrm{m} \mathrm{m}^{-2} \mathrm{~s}^{-1}\right)$ of low background photosynthetic photon flux density (PPFD) were measured in the leaves of Fagus crenata grown in a gap and understory of a Fagus crenata forest in the Naeba Mountains. The two background PPFD intensities most frequently occurred in understory and gap sites respectively. The maximum net photosynthetic rate $\left(P_{N \max }\right)$ and maximum stomatal conductance $\left(g_{\text {smax }}\right)$ were higher in the gap seedlings than in the understory seedlings. However, when the background PPFD was $25 \mu \mathrm{mol} \mathrm{m} \mathrm{m}^{-2} \mathrm{~s}^{-1}$, the net photosynthetic rate $\left(P_{25}\right)$ and stomatal conductance $\left(g_{\mathrm{s} 25}\right)$ were almost the same between the gap and understory. When the background PPFD duration was 1-min, the net photosynthetic rate $\left(P_{N}\right)$ at the end of each lightfleck increased progressively. When the background PPFD duration was 5- and 10-min, the increase in $P_{N}$ at the end of each lightfleck was less. This indicates that background PPFD duration is important to photosynthetic responses to lightflecks. The higher ratios of $P_{25} / P_{N \max }$ and $g_{\mathrm{s} 25} / g_{\mathrm{smax}}$ in the understory seedlings indicate that the understory seedlings can maintain relatively lower levels of biochemical and stomatal limitations than the gap seedlings under low light conditions. The ratios of $P_{N} / P_{N \max }$ at the end of each lightfleck $(I S)$ and light utilization efficiency of single lightflecks $\left(L U E_{\mathrm{s}}\right)$ that showed the influence of lightflecks on carbon gain were higher in the understory seedlings than in the gap seedlings when the background PPFD was $25 \mu \mathrm{mol} \mathrm{m}^{-2} \mathrm{~s}^{-1}$. This means that understory seedling are capable of utilizing fluctuating light more efficiently under low light conditions than the gap seedlings although the net carbon gain of single lightflecks $\left(C G_{\mathrm{s}}\right)$ in the understory seedlings was not higher than that in the gap seedlings. There were no significant differences in $I S$ and $L U E_{\mathrm{s}}$ between understory seedlings at a background PPFD of $25 \mu \mathrm{mol}$ $\mathrm{m}^{-2} \mathrm{~s}^{-1}$ and gap seedlings at a background PPFD of $50 \mu \mathrm{mol} \mathrm{m}^{-2} \mathrm{~s}^{-1}$. However, $C G_{\mathrm{s}}$ in gap seedlings was higher than in understory seedlings. These results provide more evidence that $F$. crenata acclimate to a natural light environment in respect to relative induction state at low background PPFD and can capture the fluctuating light at the same efficiency in both the gap and understory seedlings under natural light environments.
\end{abstract}

Key words: background light intensity and duration, carbon gain, induction state, light utilization efficiency

Photosynthetic acclimation to a changing light environment has been studied on steady-state responses to light in different species (Boardman, 1077; Chazdon, 1986; Kitajima, 1994; Chen and Klinka, 1997; Murchie and Horton, 1997). In general, leaves have a lower dark respiration rate and a lower maximum photosynthetic rate on a leaf area basis in the understory than in the gap. Shade leaves have a higher photosynthetic rate at low photosynthetic photon flux density (PPFD) than sun leaves, indicating in some studies that shade leaves acclimate to low light conditions and use low PPFD efficiently (Boardman, 1977; Han et al., 1999). However, the steady-state conditions applied in measurements of leaf photosynthesis do not hold under the transient light conditions characterized by the occurrence of sunflecks. Therefore it is also important to understand the dynamic photosynthetic responses to changes in light. There have been studies of the photosynthetic induction response in different species (Chazdon and Pearcy, 1986a; Pons et al., 1992; Kursar and Coley, 1993; Poorter and Oberbauer, 1993; Chen and Klinka, 1997; Valladares et al., 1997; Han et al., 1999). Previous studies have shown that the induction state of the photosynthetic apparatus is dependent on the capacity for RuBP regeneration (Sassenrath-Cole and Pearcy, 1992), the capacity for Rubiscocatalyzed carboxylation (Seemann et al., 1988), and leaf

\footnotetext{
${ }^{1}$ Present address: Department of Plant Ecology, Forestry and Forest Products Research Institute, Tsukuba 305-8687, Japan.

${ }^{2}$ Corresponding author (E-mail: afykaku@agr.shizuoka.ac.jp).
}

stomatal conductance (Tinoco-Ojanguren and Pearcy, 1992). Moreover, some studies suggested that the responses in leaf xylem pressure potential might play an important role in the photosynthetic response to lightflecks (Knapp et al., 1989; Knapp, 1992). Measurements of photosynthetic responses to lightflecks in controlled laboratory conditions have indicated that the ratio of measured $\mathrm{CO}_{2}$ fixation to predicted $\mathrm{CO}_{2}$ fixation from steady-state and the ratio of post-illumination $\mathrm{CO}_{2}$ fixation to total $\mathrm{CO}_{2}$ fixation decreased with the increase in the duration of a lightfleck (Chazdon and Pearcy, 1986b; Pons and Pearcy, 1992; Tang et al., 1994).

Fagus crenata Blume (Japanese beech), a late-successional and climax species, is ecologically the most important forest tree species in the cool-temperate natural forests of the mountainous zones in Japan (Ishizuka, 1974). It is moderately shade tolerant and capable of regenerating under its own canopy. However, there is a high variety of species on the forest floor, and saplings of $F$. crenata do not have a growth advantage among these species (Watanabe, 1994). In order to survive under these shade environments, it is very important to use light energy efficiently. With decreasing light availability, its specific leaf area increases and its dark respiration rate decreases (Liang et al., 1995). These changes are likely to make saplings more efficient in capturing light energy in a light-limiting environment. Moreover, the effective utilization of sunflecks in carbon gain is another method of capturing light energy more efficiently. Sunflecks can contribute up to (10 to) $90 \%$ of the total daily light intensity in some forest 
understories (Chazdon, 1986, 1988; Pfitsch and Pearcy, 1989; Chazdon and Pearcy, 1991) and can enhance daily carbon gain by up to $60 \%$ (Pearcy and Calkin, 1983; Weber et al., 1985; Chazdon, 1986; Pearcy, 1987; Pfitsch and Pearcy, 1989; Koizumi and Oshima, 1993). These studies were carried out either in tropical tree species or herbs; thus little is known about tree species in temperate and cool-temperate zones (Weber et al., 1985). To our knowledge, there is no report on F. crenata. Han et al. (1999) found that the time required for full induction was similar for gap and understory seedlings of F. crenata. A high sunfleck utilization and its contribution to carbon gain, if they exist, are ecologically important to $F$. crenata in using fluctuating light such as sunflecks.

The objectives of this study are: (1) to demonstrate the possible influences of the duration and intensity of background light in the photosynthetic induction responses to lightflecks; (2) to compare light utilization efficiency and carbon gain during lightflecks between the seedlings grown in the gap and understory.

\section{Materials and Methods \\ 1 Study site and plants}

Measurements were conducted on seedlings of Fagus crenata growing in a gap or understory of the $F$. crenata forest at Naeba Mountain in Niigata Prefecture, Japan ( $36^{\circ} 51^{\prime}$ N, $138^{\circ} 40^{\prime} \mathrm{E}$, altitude $700 \mathrm{~m}$ ), in August 2000. The climate is cool temperate with a mean annual precipitation of 1,778 $\mathrm{mm}$ near the site, according to 30-year records from 1967 to 1996 (Japanese Bureau of Meteorology). Naturally occurring seedlings (5-10 years old, 50-100 cm tall) were selected for study in both the gap and the understory. Plants growing near the center or southern side of the gap were chosen as gap samples. The gap site received direct solar irradiance for two consecutive hours from 10:30 to 12:30 during daytime. The understory site was located about $40 \mathrm{~m}$ apart from the gap site. The most frequently occurring PPFD was 25 and $50 \mu \mathrm{mol}$ $\mathrm{m}^{-2} \mathrm{~s}^{-1}$ in the understory and the gap site, respectively (Naramoto et al., 2001).

\section{Gas exchange measurements}

Gas exchange measurements were made with a portable photosynthesis measurement system (LI-6400, LI-COR Inc. Lincoln, NE, USA). A $2 \times 3 \mathrm{~cm}$ chamber was used and a LED 6400-02B lamp provided the light source. Measurements were made at a temperature of $22^{\circ} \mathrm{C}$, a relative humidity of $70 \%$ (vapor pressure deficit $8.2 \mathrm{~Pa} \mathrm{kPa}^{-1}$ ) and a $\mathrm{CO}_{2}$ concentration of $350 \mathrm{ppm}$. A gas cooler (MGK-1, Heinz Walz GmbH, Effeltrich, Germany) with a temperature controller (MGE-130, Heinz Walz) was used to control the relative humidity of inlet air. Firstly, the leaves were exposed to low background light for about $1 \mathrm{~h}$ to reach a steady-state photosynthetic rate before the series of lightflecks. Then, the leaves were exposed to lightflecks separated by a 1-, 5- and 10min low background PPFD, and were finally exposed to lightfleck continually for 30-min to obtain a fully induced maximum photosynthetic rate $\left(P_{N \max }\right)$. The lightflecks were 1-min long for all measurements, and their intensity was

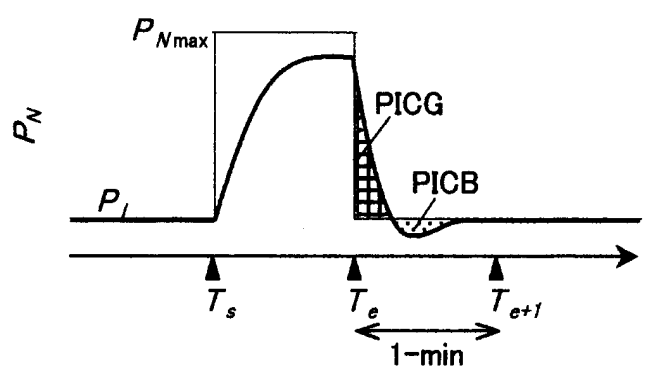

Fig. 1 A diagram to illustrate the time course of measured and predicted net photosynthetic rate $\left(P_{N}\right)$ during a 1-min lightfleck. Bold line represents the instantaneous $P_{N}$. Thin line means predicted $P_{N}$ at steady state. $P_{N \max }$ and $P_{l}$ are the steady-state rate of photosynthesis measured at high (lightfleck) and low (background) light levels, respectively. $T_{s}$ is the start time of a lightfleck. $T_{e+1}$ is $1 \mathrm{~min}$ after the end of the lightfleck $\left(\mathrm{T}_{e}\right)$. Hatched and dotted areas indicate post-illumination carbon gain (PICG) and post-illumination $\mathrm{CO}_{2}$ burst (PICB), respectively.

above the photosynthetic light saturation threshold $(1,000$ $\left.\mu \mathrm{mol} \mathrm{m}{ }^{-2} \mathrm{~s}^{-1}\right)$. The photosynthetic light saturation thresholds were approximately 400 and $200 \mu \mathrm{mol} \mathrm{m}^{-2} \mathrm{~s}^{-1}$ in the gap and understory seedlings, respectively (data not shown). The low background PPFD intensity was 25 and $50 \mu \mathrm{mol} \mathrm{m}^{-2} \mathrm{~s}^{-1}$ in the gap seedlings and $25 \mu \mathrm{mol} \mathrm{m}^{-2} \mathrm{~s}^{-1}$ in the understory seedlings. Leaves were exposed to a series of 9,4 , and 2 lightflecks, when the background PPFD duration was 1-, 5- and 10min, respectively. During the measurements, the photosynthetic rate and other data were recorded every 2 -s. The net photosynthetic rate at different background PPFDs $\left(P_{25}\right.$ and $\left.P_{50}\right)$, maximum net photosynthetic rate $\left(P_{N \max }\right)$, as well as stomatal conductance at different background PPFDs ( $g_{\mathrm{s} 25}$ and $\left.g_{\mathrm{s} 50}\right)$ and maximum stomatal conductance $\left(g_{\mathrm{smax}}\right)$ were obtained and included for statistical comparison.

\section{Calculations}

The total net carbon gain of single lightflecks $\left(C G_{s}\right)$ was calculated as (Fig. 1):

$$
C G_{s}=\int_{T_{s}}^{T_{e+1}} P_{N}(T) d T
$$

In this formula, $T_{s}$ is the start time of a lightfleck. $T_{e+1}$ is $1 \mathrm{~min}$ after the end of the lightfleck $\left(T_{e}\right)$ to take the post-illumination carbon gain/burst into account. $P_{N}(T)$ is the instantaneous photosynthetic rate at time $T$ measured at 2 -s intervals.

To evaluate the influence of lightflecks on carbon gain, the lightfleck utilization efficiency of single lightflecks $\left(L U E_{\mathrm{s}}\right)$ was calculated according to Pons and Pearcy (1992) with some modification. In brief, we took the post-illumination carbon gain/burst into the calculation (Fig. 1).

$$
L U E_{\mathrm{s}}(\%)=\frac{\int_{T_{s}}^{T_{e+1}} P_{N}(T) d T}{P_{N \max }\left(T_{e}-T_{s}\right)+P_{l}\left(T_{e+1}-T_{e}\right)} \times 100
$$

Where $P_{N \max }$ and $P_{l}$ are the steady-state rate of photosynthe+ sis measured at high (lightfleck) and low (background) light levels, respectively.

To measure the overall limitations imposed by the induction requirement during the lightflecks, the induction state of sin- 
Table 1 Gas exchange parameters for $F$. crenata grown in the gap and understory.

\begin{tabular}{|c|c|c|}
\hline Parameter & Gap & Understory \\
\hline$P_{25} \quad\left(\mu \mathrm{mol} \mathrm{m}^{-2} \mathrm{~s}^{-1}\right)$ & $\begin{array}{c}1.28 \pm 0.08 \\
(24.3 \pm 1.3)^{\mathrm{a}}\end{array}$ & $\begin{array}{r}1.36 \pm 0.09 \\
(39.7 \pm 1.8)^{\mathrm{b}}\end{array}$ \\
\hline$P_{50} \quad\left(\mu \mathrm{mol} \mathrm{m}{ }^{-2} \mathrm{~s}^{-1}\right)$ & $\begin{array}{r}2.75 \pm 0.12 \\
(46.7 \pm 1.5)\end{array}$ & - \\
\hline 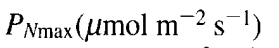 & $5.61 \pm 0.15^{\mathrm{a}}$ & $3.45 \pm 0.20^{\mathrm{b}}$ \\
\hline$g_{\mathrm{s} 25}\left(\mathrm{mmol} \mathrm{m}^{-2} \mathrm{~s}^{-1}\right)$ & $\begin{array}{l}56.7 \pm 9.0 \\
(31.6 \pm 2.3)^{\mathrm{a}}\end{array}$ & $\begin{array}{c}73.0 \pm 7.1 \\
(57.5 \pm 2.8)^{\mathrm{b}}\end{array}$ \\
\hline$g_{\mathrm{s} 50} \quad\left(\mathrm{mmol} \mathrm{m} \mathrm{m}^{-2} \mathrm{~s}^{-1}\right)$ & $\begin{array}{l}109.8 \pm 11.6 \\
(53.2 \pm 2.8)\end{array}$ & - \\
\hline 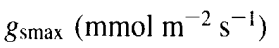 & $191.1 \pm 13.6^{\mathrm{a}}$ & $126.0 \pm 9.2^{b}$ \\
\hline
\end{tabular}

Net photosynthetic rate $\left(P_{25}, P_{50}\right)$, and stomatal conductance $\left(g_{\mathrm{s} 25}\right.$, $g_{s 50}$ ) were obtained at background light before a series of lightflecks. Subscript numbers indicate background light intensities. Maximum net photosynthetic rate $\left(P_{N \max }\right)$ and maximum stomatal conductance $\left(g_{\text {smax }}\right)$ were obtained at the end of high light (30-min long and $\left.1,000 \mu \mathrm{mol} \mathrm{m} \mathrm{m}^{-2} \mathrm{~s}^{-1}\right)$ after a series of lightflecks. Values are means for three leaves each from a different tree $\pm S E$. Different letters adjacent to a mean indicate a significance between the gap and understory ( $p<0.05$, Student's $t$-test). Values in parentheses represent mean percentage of net photosynthetic rate to $P_{N \max }$ or percentage of stomatal conductance to $g_{\text {smax }} \pm$ SE.

gle lightflecks $(I S)$ was calculated as:

$$
I S(\%)=\frac{P_{N}\left(T_{e}\right)}{P_{N \max }} \times 100
$$

where $P_{N}\left(T_{e}\right)$ is the instantaneous photosynthetic rate measured at the end of single lightflecks.

\section{Results}

\section{Gas exchange parameters under constant light}

Gap seedlings had 1.6-times higher $P_{N \max }$ and $g_{\text {smax }}$ than understory seedlings (Table 1). There were no significant differences in $P_{25}$ and $g_{\mathrm{s} 25}$ between the gap and understory. However, the ratios of $P_{25} / P_{N \max }$ and $g_{\mathrm{s} 25} / g_{\mathrm{smax}}$ in the understory seedlings were significantly higher than those in the gap seedlings.

\section{Time courses of photosynthetic responses to lightflecks}

Figure 2 shows representative time courses of the photosynthetic rate during a series of lightflecks separated by different durations of low background PPFD for the gap seedlings. When lightlecks were separated by a 1-min background PPFD (Fig. 2a), the photosynthetic rate increased gradually during the first lightfleck. From the second lightfleck, the photosynthetic rate increased dramatically at the beginning of each lightfleck, followed by a slow increase. Although the photosynthetic rate at the end of each lightfleck increased gradually during the series of lightflecks, it was still lower than $P_{N \max }$ at steady state after full induction. When the lightflecks were separated by a 5 -min background PPFD (Fig. 2b), the increase in the photosynthetic rate at the end of each lightfleck was less compared to that in the 1min background PPFD. In addition, there was no distinctive increase in photosynthetic rate between lightflecks when they were separated by a 10-min background PPFD (Fig. 2c).

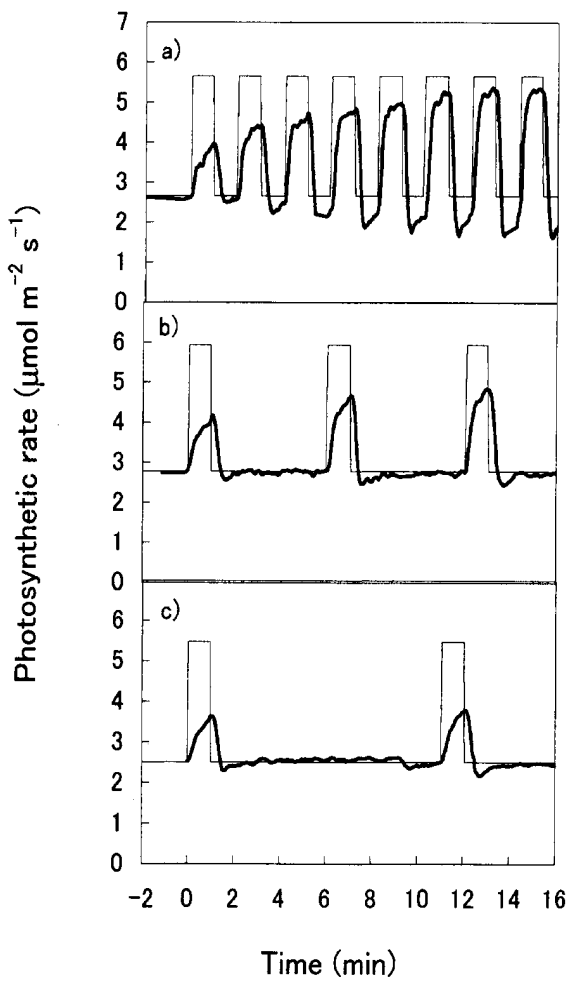

Fig. 2 Time courses of photosynthetic responses during a series of 1min lightflecks $\left(1,000 \mu \mathrm{mol} \mathrm{m} \mathrm{m}^{-2} \mathrm{~s}^{-1}\right)$ in leaves of $F$. crenata seedlings grown in the gap. Lightflecks were separated by 1 (a), 5 (b), and $10 \mathrm{~min}$ (c) of low background light $\left(50 \mu \mathrm{mol} \mathrm{m}^{-2} \mathrm{~s}^{-1}\right)$. Leaves were initially exposed to background light for about $1 \mathrm{~h}$. Bold lines are measured net photosynthetic rates. Thin lines are predicted net photosynthetic rates at steady state. The low predicted photosynthetic rate was measured before a series of lightflecks. The high predicted photosynthetic rate was measured after full induction.

When PPFD decreased, post-illumination carbon gain with an exponential decrease of the net photosynthetic rate was observed (Fig. 2). It was followed by a post-illumination $\mathrm{CO}_{2}$ burst due to photorespiration (Decker, 1959; Crews et al., 1975); i.e., the net photosynthetic rate decreased to below the rate at steady-state background PPFD. When the lightflecks were separated by a 1-min background PPFD, this post-illumination $\mathrm{CO}_{2}$ burst increased (Fig. 2a). This means that photorespiration increased, indicating progressive increases in the Rubisco activation state (Pearcy et al., 1996).

\section{Effect of background light duration}

When background PPFD was $25 \mu \mathrm{mol} \mathrm{m} \mathrm{m}^{-2} \mathrm{~s}^{-1}$, IS increased to $65 \%$ at the end of the first lightfleck in the understory seedlings (Fig. 3a). When the background PPFD duration was $1 \mathrm{~min}$, the $I S$ increased progressively. When the background PPFD duration was $5 \mathrm{~min}$, the $I S$ had no further increase from the second lightfleck. In addition, the $I S$ remained at the same level after the first lightfleck when the background PPFD duration was as long as $10 \mathrm{~min}$. Similar trends were found in the gap seedlings at a background PPFD of 25 and 50 $\mu \mathrm{mol} \mathrm{m}^{-2} \mathrm{~s}^{-1}$ (Figs. $3 \mathrm{~b}$ and $3 \mathrm{c}$ ).

$L U E_{\mathrm{s}}$ increased gradually for both gap and understory seedlings when the lightflecks were separated by a 1-min background PPFD of $25 \mu \mathrm{mol} \mathrm{m} \mathrm{m}^{-2} \mathrm{~s}^{-1}$ (Figs. 4a and 4b). 

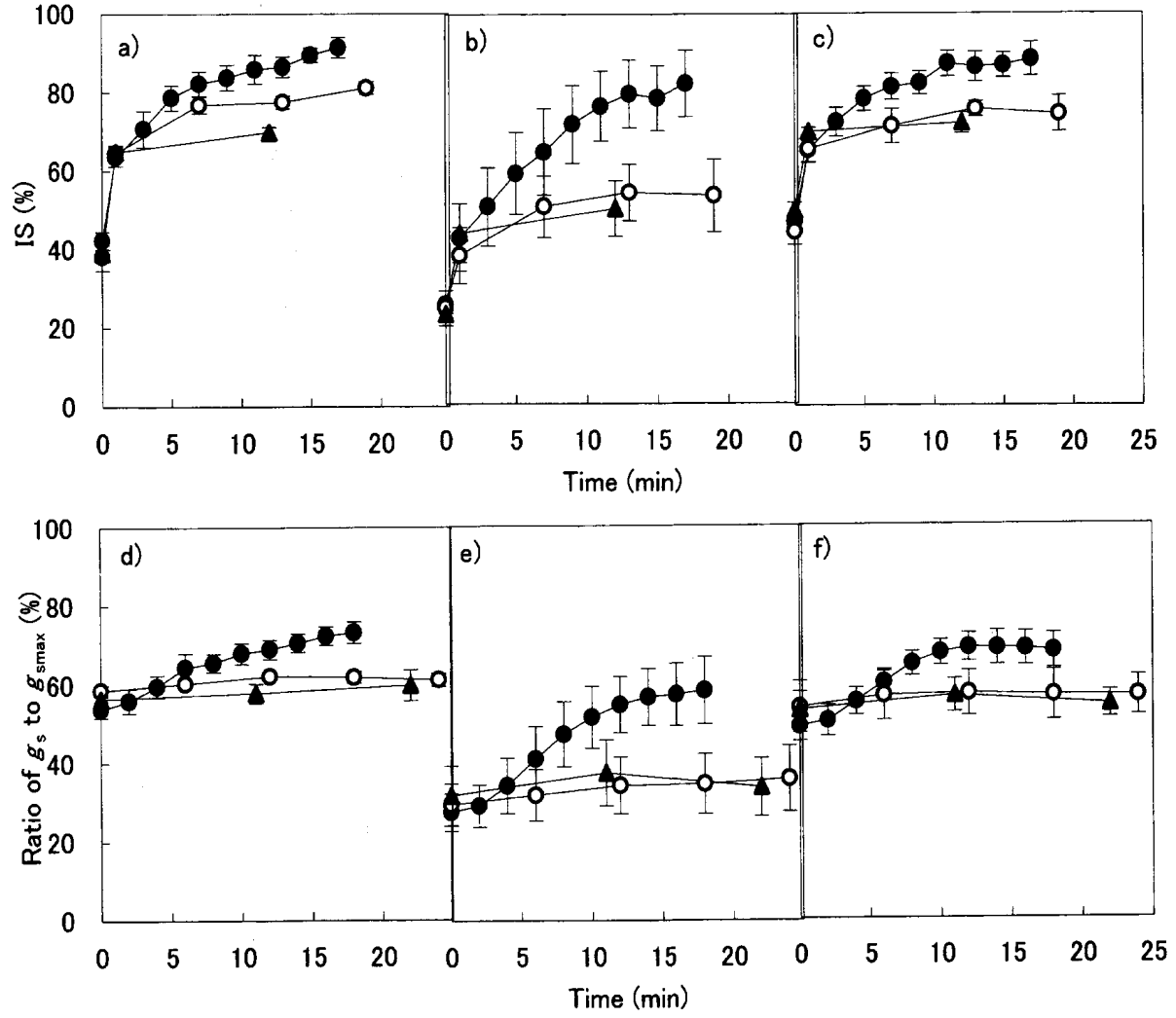

Fig. 3 Induction state (IS, upper row) at the end of each 1-min lightfleck $\left(1,000 \mu \mathrm{mol} \mathrm{m}{ }^{-2} \mathrm{~s}^{-1}\right)$ and ratio of stomatal conductance $\left(g_{\mathrm{s}}\right)$ to $g_{\mathrm{smax}}($ lower row) just before each lightfleck in leaves of $F$. crenata seedlings grown in understory (a, d) and gap (b, c, e, f). Lightflecks were separated by 1 -(closed circle), 5-(open circles) and 10-min (closed triangles) of low background light of $25 \mu \mathrm{mol} \mathrm{m}^{-2} \mathrm{~s}^{-1}$ (a, b, d, e) and $50 \mu \mathrm{mol} \mathrm{m}^{-2} \mathrm{~s}^{-1}$ (c, f). Leaves were initially exposed to low background light for about 1-h. Values are means of 3-5 leaves $\pm \mathrm{SE}$.
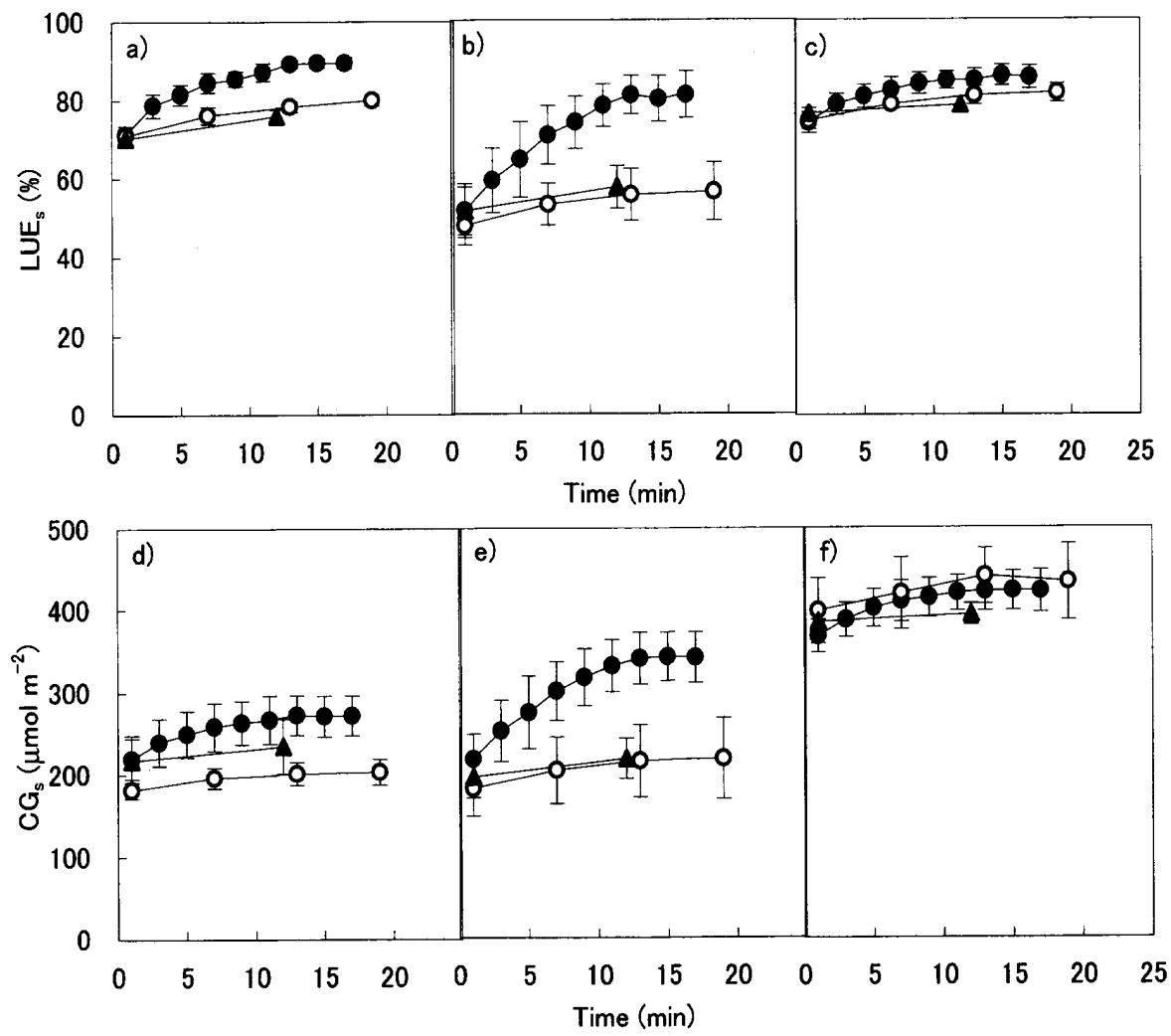

Fig. 4 Light utilization efficiency of single lightflecks $\left(L U E_{\mathrm{s}}\right.$, upper row) and total net carbon gain of single lightflecks $\left(C G_{\mathrm{s}}\right.$, lower row) in leaves of $F$. crenata seedlings grown in understory (a, d) and gap (b, c, f, e). Lightflecks were 1 min long, and their intensity was $1,000 \mu \mathrm{mol} \mathrm{m}^{-2} \mathrm{~s}^{-1}$. Lightflecks were separated by 1-(closed circle), 5-(open circles), and 10-min (closed triangles) of low background light of $25 \mu \mathrm{mol} \mathrm{m}^{-2} \mathrm{~s}^{-1}$ (a, b, d, e) and $50 \mu \mathrm{mol} \mathrm{m} \mathrm{m}^{-2} \mathrm{~s}^{-1}(\mathrm{c}, \mathrm{f})$. Leaves were initially exposed to low background light for about 1-h. Values are means of 3-5 leaves $\pm \mathrm{SE}$. 


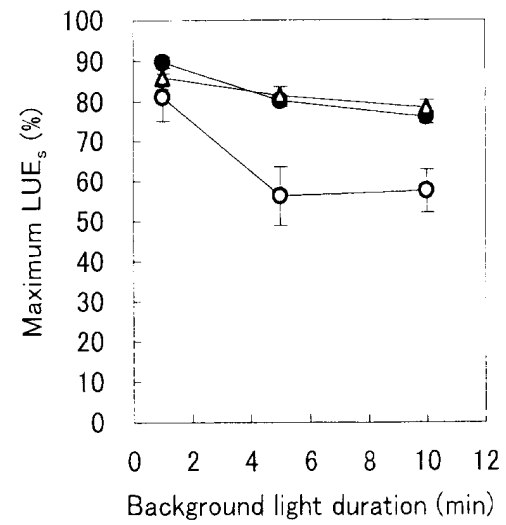

Fig. 5 The relationship between the maximum light utilization efficiency of single lightfleck $\left(L U E_{\mathrm{s}}\right)$ during a series of 1-min lightflecks $\left(1,000 \mu \mathrm{mol} \mathrm{m}^{-2} \mathrm{~s}^{-1}\right)$ and background light duration for $F$. crenata seedlings grown in gap (open symbols) and understory (closed symbols). Lightflecks were separated by 1,5 , and $10 \mathrm{~min}$ of low background light of $25 \mu \mathrm{mol} \mathrm{m}{ }^{-2} \mathrm{~s}^{-1}$ (circles) and $50 \mu \mathrm{mol} \mathrm{m}^{-2} \mathrm{~s}^{-1}$ (triangles). Leaves were initially exposed to low background light for about $1 \mathrm{~h}$. Values are means of 3-5 leaves \pm SE.

By contrast, $L U E_{\mathrm{s}}$ increased much more slowly when the lightflecks were separated by a 5- and 10-min background PPFD. The effect of background PPFD duration on $L U E_{\mathrm{s}}$ was less when the background PPFD intensity was $50 \mu \mathrm{mol} \mathrm{m}^{-2}$ $\mathrm{s}^{-1}$ (Fig. 4c). The trends in $C G_{\mathrm{s}}$ were similar to the respective $L U E_{\mathrm{s}}$ trends for all seedlings and under all transit light conditions (Figs. 4d, 4e, and 4f).

The relationship between the maximum $L U E_{\mathrm{s}}$ during a series of lightflecks and the background PPFD duration is shown in Fig. 5. When the background PPFD was $25 \mu \mathrm{mol}$ $\mathrm{m}^{-2} \mathrm{~s}^{-1}$ and its duration was $1 \mathrm{~min}, L U E_{\mathrm{s}}$ reached a maximum value of $81 \%$ for gap seedlings. By contrast, when the background PPFD duration was 5- and 10-min, the maximum $L U E_{\mathrm{s}}$ was lower than $60 \%$. The same trends were found in the gap seedlings at a background PPFD of $50 \mu \mathrm{mol} \mathrm{m}^{-2} \mathrm{~s}^{-1}$ and in the understory seedlings at a background PPFD of 25 $\mu \mathrm{mol} \mathrm{m}{ }^{-2} \mathrm{~s}^{-1}$. The maximum $L U E_{\mathrm{s}}$ was significantly higher in the understory seedlings than in the gap seedlings when the background PPFD duration was 5 and 10 min.

\section{Effect of background light intensity}

In the gap seedlings, the $I S$ (Figs. $3 \mathrm{~b}$ and $3 \mathrm{c}$ ), $C G_{\mathrm{s}}$ (Figs. $4 \mathrm{e}$ and $4 \mathrm{f}$ ) and $L U E_{\mathrm{s}}$ (Figs. $4 \mathrm{~b}$ and $4 \mathrm{c}$ ) were higher at a background PPFD of 50 than of $25 \mu \mathrm{mol} \mathrm{m}^{-2} \mathrm{~s}^{-1}$, when the background PPFD duration was 5 and 10 min. When the background PPFD duration was $1 \mathrm{~min}$, these differences between two background PPFD intensities gradually decreased. The $C G_{\mathrm{s}}$ at the first lightfleck was about twice as high at a background light of 50 than $25 \mu \mathrm{mol} \mathrm{m}^{-2} \mathrm{~s}^{-1}$. Until the sixth lightfleck, the $C G_{\mathrm{s}}$ at a background PPFD of $50 \mu \mathrm{mol} \mathrm{m}^{-2} \mathrm{~s}^{-1}$ was significantly higher than at $25 \mu \mathrm{mol} \mathrm{m}{ }^{-2} \mathrm{~s}^{-1}$.

When the background PPFD intensity was $25 \mu \mathrm{mol} \mathrm{m}^{-2} \mathrm{~s}^{-1}$, the $I S$ and $L U E_{\mathrm{s}}$ were higher in the understory seedlings than in the gap seedlings (Figs. $4 \mathrm{a}$ and $4 \mathrm{~b}$ ). The $C G_{\mathrm{s}}$ was almost the same for the gap and understory seedlings when the background PPFD duration was 5 and 10 min (Figs. $4 \mathrm{~d}$ and $4 \mathrm{e}$ ). When the background PPFD duration was $1 \mathrm{~min}, C G_{\mathrm{s}}$ of the first lightfleck was almost the same for the gap and understory seedlings and $C G_{\mathrm{s}}$ of the ninth lightfleck were about 1.25 times higher in the gap seedlings than in the understory seedlings.

The $L U E_{\mathrm{s}}$ in the gap seedlings at a background PPFD of 50 $\mu \mathrm{mol} \mathrm{m} \mathrm{m}^{-2} \mathrm{~s}^{-1}$ were similar to those in the understory seedlings at a background PPFD of $25 \mu \mathrm{mol} \mathrm{m} \mathrm{m}^{-2} \mathrm{~s}^{-1}$ for all three background PPFD durations (Figs. 4a and 4c). However, the gap seedlings had significantly higher $C G_{\mathrm{s}}$ than the understory seedlings (Figs. 4d and 4f).

\section{Discussion}

Both background PPFD intensity and duration influenced the $I S, L U E_{\mathrm{s}}$, and $C G_{\mathrm{s}}$ in $F$. crenata seedlings. The $I S, L U E_{\mathrm{s}}$, and $C G_{\mathrm{s}}$ were higher when background PPFD intensity was higher and background PPFD duration was shorter (Figs. 3, 4, and 5). These results are generally consistent with previous studies (Chazdon and Pearcy, 1986a, b; Sassenrath-Cole and Pearcy, 1994; Valladares et al., 1997; Han et al., 1999). Photosynthetic induction response to lightflecks can be separated into two phases: a fast-induction phase that requires $1-2 \mathrm{~min}$ for the regeneration of RuBP and the build up of the Calvincycle metabolites (Kirschbaum and Pearcy, 1988; Sassenrath-Cole and Pearcy, 1992), followed by a slow-induction phase, lasting 5-30 min or more, in which Rubisco is activated and stomata open (Kirschbaum and Pearcy, 1988; Pearcy, 1990). These biochemical and stomatal limitations to photosynthetic response are affected by the light conditions to which leaves are exposed before an increase in light intensity (Sassenrath-Cole and Pearcy, 1994; Han et al., 1999). When the background PPFD duration was $1 \mathrm{~min}$, the ratio of $g_{\mathrm{s}} / g_{\text {smax }}$ increased during a series of lightflecks (Figs. 3d, 3e, and $3 \mathrm{f}$ ). This indicates that the stomatal limitation to photosynthetic apparatus decreases during a series of lightflecks. When the background PPFD duration was 5 and $10 \mathrm{~min}$, the ratio of $g_{s} / g_{\text {smax }}$ did not increase very much, indicating that the stomatal limitations do not vary greatly during a series of lightflecks. According to the description of fully induced leaves by Sassenrath-Cole and Pearcy (1992, 1994), when the background PPFD duration is within 1 min, the RuBP concentration dose not decrease much and the photosynthetic response to re-illumination is fast. However, when the background PPFD duration is longer than 5-min, the RuBP concentration decreases dramatically and the photosynthetic response to re-illumination is limited by the regeneration of RuBP. Thus, the biochemical and stomatal limitations to photosynthetic response that decreases during lightflecks increase during background PPFD with an increase in the background PPFD duration. Therefore, photosynthetic response is limited with the longer background PPFD (5- and 10-min) compared to a background PPFD of 1 min.

$P_{N \max }$ and $g_{\mathrm{smax}}$ were significantly higher in the gap seedlings than in the understory seedlings (Table 1). These results have been reported in many studies (Boardman, 1977; Chazdon, 1986; Kitajima, 1994; Liang et al., 1995; Chen and Klinka, 1997; Murchie and Horton, 1997; Han et al., 1999). Moreover, some studies have described shade leaves 
as having photosynthetic rates and using light more efficiently than sun leaves under a low PPFD (Boardman, 1977; Han et al., 1999). In this study, $P_{25}$ in both the gap and understory seedlings was almost the same (Table 1). However, these results also suggest that the understory seedlings acclimate to use a low PPFD efficiently, considering that the $P_{N \max }$ in the understory seedlings was lower than that in the gap seedlings.

When the background PPFD was $25 \mu \mathrm{mol} \mathrm{m}{ }^{-2} \mathrm{~s}^{-1}, I S$ and $L U E_{\mathrm{s}}$ were higher in the understory seedlings than in the gap seedlings (Figs. 3a, 3b, 4a, and 4b). These results agree with previous studies (Chazdon and Pearcy, 1986b; Pons and Pearcy, 1992; Tang et al., 1994). However, there was no significant difference in $C G_{\mathrm{s}}$ at each lightfleck between the gap and understory seedlings except after the 6th lightfleck with a background PPFD of 1-min (Figs. 4d and 4e). The gap seedlings did not exhibit higher photosynthetic capacity after lightflecks when leaves were not sufficiently induced. The ratios of $P_{25} / P_{N \max }$ and $g_{s 25} / g_{\text {smax }}$ in the understory seedlings were significantly higher than the ratios in the gap seedlings (Table 1). This shows that the understory seedlings can maintain relatively lower levels of biochemical and stomatal limitations at a low PPFD and exhibit a photosynthetic capacity in response to lightflecks more readily than the gap seedlings. Thus the understory seedlings were thought to use lightflecks efficiently, considering that the $P_{N \max }$ in the understory seedlings was lower than that in the gap seedlings. However, $C G_{\mathrm{s}}$ in the understory seedlings was not found to be higher than that in the gap seedlings.

The $I S$ and $L U E_{\mathrm{s}}$ for the understory seedlings at a background PPFD of $25 \mu \mathrm{mol} \mathrm{m} \mathrm{m}^{-2} \mathrm{~s}^{-1}$ were similar to those of the gap seedlings at a background PPFD of $50 \mu \mathrm{mol} \mathrm{m}^{-2} \mathrm{~s}^{-1}$ (Figs. 3a, 3c, 4a, and 4c). These relative photosynthetic responses to lightflecks correlate with the relative biochemical and stomatal limitations before the lightflecks. The ratios of $P_{25} / P_{N \max }$ and $g_{\mathrm{s} 25} / g_{\mathrm{smax}}$ in the understory seedlings are similar to the ratios of $P_{50} / P_{N \max }$ and $g_{550} / g_{\text {smax }}$ in the gap seedlings (Table 1), indicating that the biochemical and stomatal limitations at these background PPFDs are relatively the same between the gap and understory seedlings. These light intensities were the most frequently occurring PPFDs for the two sites (Naramoto et al., 2001). Therefore, $L U E_{\mathrm{s}}$ to sunflecks under a natural light environment may be almost the same in both the gap and understory seedlings. Thus, this study shows that both gap and understory seedlings of $F$. crenata acclimate to their natural light environments in the respect to relative biochemical and stomatal limitations to photosynthetic apparatus at low background PPFD and respond to sunflecks with the same efficiency.

This study was funded by the research project, Evaluation of Total $\mathrm{CO}_{2}$ Budget in Forest Ecosystems, coordinated by the Ministry of Agriculture, Forestry and Fisheries of Japan.

\section{Literature cited}

Boardman, N.K. (1977) Comparative photosynthesis of sun and shade plants. Ann. Rev. Plant Physiol. 28: 355-377.

Chazdon, R.L. (1986) Light variation and carbon gain in rain forest understory palms. J. Ecol. 74: 995-1012.

Chazdon, R.L. (1988) Sunflecks and their importance to forest understory plants. Adv. Ecol. Res. 18: 1-63.

Chazdon, R.L. and Pearcy, R.W. (1986a) Photosynthetic responses to light variation in rain forest species. I. Induction under constant and fluctuating conditions. Oecologia 69: 517-523.

Chazdon, R.L. and Pearcy, R.W. (1986b) Photosynthetic responses to light variation in rain forest species. II. Carbon gain and photosynthetic efficiency during lightflecks. Oecologia 69: 524-531.

Chazdon, R.L. and Pearcy, R.W. (1991) The importance of sunflecks for forest understory plants. Bioscience 41: 760-766.

Chen, H.Y.H. and Klinka, K. (1997) Light availability and photosynthesis of Pseudotsuga menziesii seedlings grown in the open and the forest understorey. Tree Physiol. 17: 23-29.

Crews, C.E., Vines, H.M., and Black, C.C.Jr. (1975) Postillumination burst of carbon dioxide in crassulacean acid metabolism plants. Plant Physiol. 55: 652-657.

Decker, J.P. (1959) Comparative responses of carbon gain dioxide outburst and uptake in tabacco. Plant Physiol. 34: 100-102.

Han, Q., Yamaguchi, E., Odaka, N., and Kakubari, Y. (1999) Photosynthetic induction responses to variable light under field conditions in three species grown in the gap and understory of a Fagus crenata forest. Tree Physiol. 19: 625-634.

Ishizuka, K. (1974) Mountain vegetation. In The flora and vegetation of Japan. Numata, M. (ed.), 294pp, Kodansha, Tokyo, 173-210.

Kirschbaum, M.U.F. and Pearcy, R.W. (1988) Gas exchange analysis of relative importance stomatal and biochemical factors in photosynthetic induction in Alocasia macrorrhiza. Plant Physiol. 86: 782-785.

Kitajima, K. (1994) Relative importance of photosynthetic traits and allocation patterns as correlates of seedling shade tolerance of 13 tropical trees. Oecologia 98: 419-428.

Knapp, A.K. (1992) Leaf gas exchange in Quercus macrocarpa (Fagaceae): Rapid stomatal responses to variability in sunlight in a tree growth form. Am. J. Bot. 79: 599-604.

Knapp, A.K., Smith, W.K., and Young, D.R. (1989) Importance of intermittent shade to the ecophysiology of subalpine herbs. Funct. Ecol. 3: 753-758.

Koizumi, H. and Oshima, Y. (1993) Light environment and carbon gain of understory herbs associated with sunflecks in a warm temperate deciduous forest. Ecol. Res. 8: 135-142.

Kursar, T.A. and Coley, P.D. (1993) Photosynthetic induction times in shade tolerant species with long and short-lived leaves. Oecologia 93: 165-170.

Liang, N., Nagayama, M., Nakata, M., and Maruyama, K. (1995) Growth, photosynthesis and nitrogen content in Japanese beech (Fagus crenata $\mathrm{Bl}$.) seedlings grown under five irradiances. Photosynthetica 31: 257-268.

Murchie, E.H. and Horton, P. (1997) Acclimation of photosynthesis to irradiance and spectral quality in British plant species: Cholorophyll content, photosynthetic capacity and habitat preference. Plant Cell Environ. 20: 438-448.

Naramoto, M., Han, Q., and Kakubari, Y. (2001) The influence of previous irradiance on photosynthetic induction in three species grown in the gap and understory of a Fagus crenata forest. Photosynthetica 39: 545-552.

Pearcy, R.W. (1987) Photosynthetic gas exchange responses of Australian tropical forest trees in canopy, gap and understory microenvironments. Funct. Ecol. 1: 169-178.

Pearcy, R.W. (1990) Sunflecks and photosynthesis in plant canopies. Annu. Rev. Plant Physiol. Plant Mol. Biol. 41: 421-453.

Pearcy, R.W. and Calkin, H.W. (1983) Carbon dioxide exchange of $C_{3}$ and $\mathrm{C}_{4}$ tree species in the understory of Hawaiian forest. Oecologia 58: 26-32.

Pearcy, R.W., Krall, J.P., and Sassenrath-Cole, G.F. (1996) Photosynthesis in fluctuating light environments. In Photosynthesis and the environment. Baker, N.R. (ed.), 491 pp, Kluwer Academic Publishers, 321-346.

Pfitsch, W.A. and Pearcy, R.W. (1989) Daily carbon gain by Adenocaulon bicolor (Asteraceae), a redwood forest understory herb, in relation to its light environment. Oecologia 80: 465-470.

Pons, T.L. and Pearcy, R.W. (1992) Photosynthesis in flashing light in soybean leaves grown in different conditions. II. Lightfleck utilization efficiency. Plant Cell Environ. 15: 577-584. 
Pons, T.L., Pearcy, R.W., and Seemann, J.R. (1992) Photosynthesis in flashing light in soybean leaves grown in different conditions. I. Photosynthetic induction state and regulation of ribulose-1,5-bisphosphate carboxylase activity. Plant Cell Environ. 15: 569-576.

Poorter, L. and Oberbauer, S.F. (1993) Photosynthetic induction response of two rainforest tree species in relation to light environment. Oecologia 96: 193-199.

Sassenrath-Cole, G.F. and Pearcy, R.W. (1992) The role of ribulose-1,5bisphosphate regeneration in the induction requirement of photosynthetic $\mathrm{CO}_{2}$ exchange under transient light conditions. Plant Physiol. 99: 227-234.

Sassenrath-Cole, G.F. and Pearcy, R.W. (1994) Regulation of photosynthetic induction state by magnitude and duration of low light exposure. Plant Physiol. 105: 1115-1123.

Seemann, J.R., Kirschbaum, M.U.F., Sharkey, T.D., and Pearcy, R.W. (1988) Regulation of ribulose-1,5-bisphosphoate carboxylase activity in Alocasia macrorrhiza in response to step changes in irradiance. Plant Physiol. 88: 148-152.
Tang, Y., Koizumi, H., Satoh, M., and Washitani, I. (1994) Characteristics of transient photosynthesis in Quercus serrata seedlings grown under lightfleck and constant regimes. Oecologia 100: 463-369.

Tinoco-Ojanguren, C. and Pearcy, R.W. (1992) Dynamic stomatal behavior and its role in carbon gain during sunflecks of a gap phase and an understory Piper species acclimated to high and low light. Oecologia 92: 222-228.

Valladares, F., Allen, M.T., and Pearcy, R.W. (1997) Photosynthetic response to dynamic light under field conditions in six tropical rainforest shrubs occuring along a light gradient. Oecologia 111: 505-514.

Watanabe, S. (1994) Specia of trees. 450pp, University of Tokyo Press, Tokyo. (in Japanese)

Weber, J.A., Jurik, T.W., Tenhunen, J.D., and Gates, D.M. (1985) Analysis of gas exchange in seedlings of Acer saccharum: Integration of field and laboratory studies. Oecologia 65: 338-347.

(Received October 29, 2001; Accepted June 21, 2002) 